\title{
PERAN AUDITOR INTERNAL DALAM MEWUJUDKAN KEPATUHAN ORGANISASI PERANGKAT DAERAH (OPD) DI BIDANG PENATAUSAHAAN KEUANGAN PADA KANTOR INSPEKTORAT KABUPATEN MINAHASA UTARA
}

\author{
Andini Anjali ${ }^{1}$, Jenny Morasa ${ }^{2}$, Stanley Kho Walandouw ${ }^{2}$ \\ ${ }^{1,2}$ Jurusan Akuntansi, Fakultas Ekonomi dan Bisnis, Universitas Sam Ratulangi, Jl. Kampus Bahu, Manado, \\ 95115, Indonesia \\ ${ }^{1}$ E-mail: anjalyworang26@gmail.com
}

\begin{abstract}
The role of internal audit in this case is that government internal auditors play an important role in the government system, namely as a supervisory function where the internal auditors are given the responsibility of examining, evaluating and carrying out the supervisory function. This study aims to determine the role of the Inspectorate as an internal government auditor in realizing the compliance of Regional Apparatus Organizations (OPD) in the field of financial administration. Data collection techniques using interviews and documentation. Based on the research results, it is known that the Inspectorate of North Minahasa Regency as the government's internal auditor has a very important role in supervising the financial administration sector. This is evidenced by the implementation of the supervisory function in internal audit, namely planning the supervision program, formulating policies and monitoring facilities as well as examining, investigating, testing and evaluating the supervisory duties as well as monitoring performance and finance by the Regional Apparatus Organization (OPD) in North Minahasa Regency. Apart from overseeing and examining the government internal auditors also play a role in detecting fraud.
\end{abstract}

Keywords: the role of internal audit; government internal auditor; oversight function

\section{PENDAHULUAN}

Dalam pengelolaan Negara, pemerintah membutuhkan dana yang besar dalam penataan dan pembangunan Negara. Dana harus didistribusikan secara merata dan adil sesuai dengan kebutuhan tiap sektor sehingga penggunaan dana dapat dipertanggungjawabkan, karenanya dibutuhkan pengelolaan dan pengawasan dalam menjalankan pemerintahan untuk memperoleh pertanggungjawaban yang efektif dan efisien. Dalam meminimalisir akibat atau resiko tuntutan hukum terhadap aparatur pemerintah dalam penyimpangan penggunaan anggaran, dibutuhkan auditor sektor publik yang berkualitas dalam pengawasan keuangan pemerintah.

Audit internal merupakan suatu aktivitas penilaian yang independen dalam organisasi yang bertujuan meneliti kembali terlebih khusus di bidang akuntansi keuangan yang berpengaruh dalam kinerja organisasi sebagai landasan dalam memberikan servis pada manajemen. Peran penting auditor internal dalam membantu manajemen tidak lain untuk tercapai kinerja di dalam organisasi agar dapat berjalan dengan baik. Auditor internal merupakan pegawai yang tentu sangat bergantung pada organisasi dimana mereka bekerja. Hal ini menunjukan bahwa auditor internal seolah-olah tidaklah independen sehingga diragukan kualitas hasil audit yang dilakukan. Peran yang dilakukan auditor yaitu menjadi suatu pemecah masalah dengan menggunakan problem solving method atau pemecah masalah yang rasional, auditor dituntun mampu menyelesaikan tugas. 


\section{TINJAUAN PUSTAKA}

Akuntansi. Kartikahadi et al. (2016:3) menyatakan bahwa akuntansi adalah suatu sistem informasi keuangan yang bertujuan untuk menghasilkan dan melaporkan informasi yang relevan bagi berbagai pihak yang berkepentingan. Bahri (2016:2) menyatakan bahwa akuntansi adalah seni pencatatan, penggolongan, pengikhtisaran dan pelaporan atas suatu transaksi dengan cara sedemikian rupa, sistematis dari segi isi dan berdasarkan standar yang diakui umum.Wibowo (2016:2) menyatakan bahwa akuntansi merupakan suatu prosedur untuk mengakui, pencatatan dan korespondensi bursa keuangan dari sebuah perusahaan atau organisasi. Hal tersebut berarti akuntansi adalah sebuah sistem informasi yang mengakui dan mencatat kegiatan transaksi keuangan yang akan disajikan dalam bentuk laporan keuangan.

Akuntansi sektor publik. Pangkey dan Pinatik (2015) menyatakan bahwa akuntansi sektor publik adalah akuntansi yang digunakan untuk mencatat peristiwa ekonomi pada organisasi nirlaba. Secara sederhana, akuntansi sektor publik, seperti partai politik, masjid, puskesmas, rumah sakit, sekolah atau universitas, lembaga swasta masyarakat dan pemerintah pusat.Ratmono (2015) menyatakan bahwa akuntansi sektor publik adalah proses pengidentifikasian, pengukuran, pencatatan dan pelaporan transaksi keuangan dari entitas pemerintah daerah dalam rangka pengambilan keputusan ekonomi yang diperlukan oleh pihak eksternal.Erlina, dkk (2015) menyatakan bahwa Akuntansi sektor publik merupakan alat informasi pemerintah untuk alat informasi kepada publik.

Auditor pemerintah.Wijayanto (2017) mengatakan bahwa auditor pemerintah adalah auditor yang bertugas melakukan audit atas keuangan pada instansi-instansi pemerintah. Di Indonesia, auditor pemerintah dapat dibagi menjadi dua yaitu:

1. Auditor internal pemerintah atau yang lebih dikenal sebagai Aparat Pengawasan Internal Pemerintah (APIP) yang dilaksanakan oleh Badan Pengawasan Keuangan dan Pembangunan (BPKP), Inspektorat Jenderal Departemen/LPND dan Badan Pengawasan Daerah, guna melayani kebutuhan pemerintah. Porsi pertama upaya audit BPKP adalah dikerahkan untuk mengevaluasi efisiensi dan efektivitas operasional berbagai program pemerintah.

2. Auditor eksternal yang dilaksanakan oleh Badan Pemeriksa Keuangan (BPK). Badan Pemeriksa Keuangan merupakan badan yang didirikan berdasarkan konstitusi Indonesia. Dipimpin oleh seorang kepala, BPK melapor dan bertanggung jawab sepenuhnya kepada DPR. BPK mengaudit sebagian besar informasi keuangan yang dibuat oleh berbagai macam badan pemerintah baik pusat maupun daerah sebelum dikerahkan kepada DPR. Oleh karena kuasa dan penerimaan badan-badan pemerintah ditentukan oleh undang-undang, maka audit yang dilaksanakan difokuskan pada audit ketaatan.

Inspektorat. Menurut Siradja et al. (2015) Inspektorat daerah mempunyai fungsi perencanaan program pengawasan, perumusan kebijakan dan fasilitas pengawasan, pemeriksaan, pengusutan, pengujian dan penilaian tugas pengawasan, dan pengawasan internal terhadap kinerja dan keuangan serta pelaksanaan tugas lain yang diberikan bupati di bidang pengawasan. Inspektorat daerah sebagai auditor internal pemerintah memiliki peran dan posisi yang sangat strategis baik ditinjau dari aspek-aspek fungsi manajemen maupun dari segi pencapaian visi dan misi serta program-program pemerintah. Inspektorat Daerah dipimpin oleh inspektur dan dalam melaksanakan tugas bertanggung jawab langsung kepada Gubernur atau Bupati secara teknis administratif mendapat pembinaan dari Sekretaris Daerah, diangkat dan diberhentikan oleh Gubernur atau Bupati sesuai ketentuan atau peraturan perundang-undang (Damopoli 2017). Inspektorat daerah yang bekerja dalam organisasi pemerintah daerah memiliki tugas pokok yang menentukan apakah kebijakan dan prosedur yang ditetapkan oleh manajemen puncak (kepala daerah) telah dipatuhi dan berjalan sesuai rencana, menentukan baik atau tidak pemeliharaan terhadap kekayaan daerah, menentukan efisiensi dan efektivitas prosedur dan kegiatan pemerintah daerah, serta tidak 
kalah penting menentukan keandalan informasi yang dihasilkan oleh berbagai satuan kerja sebagai bagian yang integral dalam organisasi pemerintah daerah (Ardiyanti et al., 2016).

\section{Peraturan Perundang-undang Mengenai Audit Internal}

1. Undang-Undang Nomor 17 Tahun 2003 tentang Keuangan Negara;

2. Undang-Undang Nomor 1 Tahun 2004 tentang Perbendaharaan Negara;

3. Undang-Undang Nomor 15 Tahun 2004 tentang Pemeriksaan Pengelolaan dan Tanggung Jawab Keuangan Negara;

4. Peraturan Pemerintah Nomor 24 Tahun 2005 tentang Standar Akuntansi Pemerintahan;

5. Peraturan Pemerintah Nomor 6 Tahun 2006 tentang Pengelolaan Barang Milik Negara/Daerah;

6. Peraturan Pemerintah Nomor 8 Tahun 2006 tentang Pelaporan Keuangan dan Kinerja Instansi Pemerintah;

7. Peraturan Pemerintah Nomor 60 Tahun 2008 tentang Sistem Pengendalian Internal Pemerintah;

8. Peraturan Menteri Dalam Negeri Nomor 4 Tahun 2008 tentang Pedoman Pelaksanaan Reviu atas Laporan Keuangan Pemerintah Daerah.

Tanggung jawab auditor internal. Rusdiana dan Saptaji (2018:257) menyatakan bahwa tanggung jawab auditor internal dalam organisasi juga harus ditetapkan secara jelas oleh pimpinan. Tanggung jawab tersebut harus memberikan keleluasan auditor internal untuk melakukan audit terhadap catatan-catatan, harta milik dan aktivitas yang sedang berjalan dan para pegawai badan usaha. Auditor internal bertanggung jawab menyediakan jasa analisis, evaluasi, memberikan keyakinan, rekomendasi dan informasi kepada manajemen entitas dan dewan komisaris atau pihak lain yang setara. Auditor internal mempertahankan objektivitas yang berkaitan dengan aktivitas yang diaudit.Dapat disimpulkan bahwa auditor dalam menjalankan tugas dapat memberikan informasi dan saran-saran kepada pihak manajemen atas kelemahan yang ditemukan dan mengkoordinasikan aktivitas-aktivitas yang ada di dalam perusahaan untuk mencapai tujuan audit dan tujuan perusahaan (Mulyadi 2017).

Independensi. Menurut Arens (dalam Oktavia, 2005) menyatakan bahwa independensi dalam audit berarti cara pandang tidak memihak dalam pelaksanaan pengujian evaluasi hasil, pemeriksaan dan penyusunan laporan audit. Independensi merupakan dasar dari profesi auditing. Hal itu berarti bahwa auditor akan bersikap netral terhadap entitas dan oleh karena itu akan bersikap objektif. Publik dapat memercayai fungsi auditor karena auditor bersikap tidak memihak serta mengakui kewajiban untuk bersikap adil (Boynton et al. dalam Raya 2016:17). Caley (dalam Fransiska dan Betri, 2015) menyatakan bahwa independensi auditor dari segi integritas dengan pendapat akuntan atas laporan keuangan, independensi meliputi: (1) kepercayaan terhadap diri sendiri yang terdapat pada beberapa orang profesional; dan (2) independensi berarti adanya kejujuran dalam diri auditor dalam mempertimbangkan fakta dan adanya pertimbangan yang objektif tidak memihak dalam diri auditor dalam merumuskan dan menyatakan pendapat.

\section{METODE PENELITIAN}

Jenis penelitian yang dilakukan menggunakan pendekatan kualitatif, dengan metode etnografi. Jenis penelitian ini dipilih karena dapat menggambarkan realita empirik dibalik fenomena secara mendalam, rinci dan tuntas. Metode kualitatif adalah penelitian yang digunakan untuk meneliti pada kondisi objek yang alamiah, dimana peneliti sebagai instrumen kunci, teknik pengumpulan data dilakukan secara gabungan, analisis data bersifat induktif dan hasil penelitian kualitatif lebih menekankan makna dari pada generalisasi. Penelitian ini berfokus pada peran auditor internal Inspektorat Kabupaten Minahasa Utara sebagai pengawas di bidang penatausahaan keuangan Organisasi Perangkat Daerah (OPD). Sumber data dalam penelitian ini ada 2 yaitu data primer dan data sekunder. 
Data primer berupa yaitu data yang diperoleh langsung pada Kantor Inspektorat Kabupaten Minahasa Utara berupa hasil wawancara dengan narasumber. Data sekunder yaitu Peraturan-peraturan dan data pendukung yang menurut penulis dapat memperkuat penemuan dan melengkapi informasi. Prosedur pengumpulan data dalam penelitian ini adalah dengan mengumpulkan data sesuai tata cara penelitian sehingga diperoleh data yang dibutuhkan dengan menggunakan teknik wawancara dan dokumentasi.

\section{HASIL PENELITIAN DAN PEMBAHASAN}

\subsection{Hasil penelitian}

Inspektorat sebagai auditor internal pemerintah. Inspektorat sebagai auditor internal pemerintah memegang peranan yang penting dalam sistem pemerintahan, dimana sebagai fungsi pengawasan (controlling). Auditor internal bertanggung jawab dalam mengevaluasi dan menilai fungsi-fungsi manajemen, perencanaan (planning), pengorganisasian (organizing), pengarahan (directing), dan koordinasi (coordinating) agar tujuan organisasi dapat tercapai. Dalam makna lama, Inspektorat sebagaiauditor internal pemerintah didefinisikan sebagai penilai independen yang dilaksanakan dalam organisasi untuk mereviu, mengevaluasi dan melaporkan kecukupan pengendalian internal organisasisebagai jasa kepada organisasi yang bertujuan untuk meningkatkan efektivitas pengendalian dengan biaya yang layak. Dalam makna yang baru, Inspektorat sebagai auditor internal pemerintah tidak hanya membantu mengawasi apakah pemerintah telah mengerjakan yang harus dikerjakan, membelanjakan uang sesuai dengan tujuan yang diinginkan dan taat kepada peraturan perundang-undang yang berlaku, namun juga memberikan jasa konsultasi dalam rangka meningkatkan kinerja pemerintah serta mampu mengidentifikasi perkembangan dan tantangan-tantangan yang akan dihadapi oleh pemerintah.

Tugas pokok dan fungsi inspektorat. Peraturan Bupati Nomor 72 Tahun 2016 tentang Tugas dan Fungsi serta Tata Kerja Inspektorat tipe B Kabupaten Minahasa Utara. Dalam melaksanakan tugas, Inspektorat Pemerintah Kabupaten Minahasa Utara mempunyai tugas dan fungsi:

1. Tugas Pokok. Tugas pokok Inspektorat Kabupaten Minahasa Utara adalah membantu Bupati dalam melakukan pengawasan terhadap pelaksanaan urusan pemerintahan di daerah, pelaksanaan pembinaan atas penyelenggaraan desa serta pembinaan dan pengawasan tugas pembantuan oleh perangkat daerah.

2. Fungsi

a. Perencanaan Program Pengawasan.

b. Perumusan Kebijakan teknis bidang pembinaan, pengawasan dan Fasilitas Pengawasan.

c. Pemeriksaan, Pengusutan, Pengujian dan Penilaian Tugas Pengawasan.

d. Pelaksanaan pengawasan internal terhadap kinerja dan keuangan melalui audit, reviu, evaluasi, pemantauan dan kegiatan pengawasan lainnya;

e. Pelaksanaan pengawasan untuk tujuan tertentu atas penugasan Bupati;

f. Penyusunan laporan hasil pengawasan;

g. Pelaksanaan administrasi Inspektorat Kabupaten.

Jabatan fungsional auditor. Berdasarkan Peraturan Badan Pengawasan Keuangan dan Pembangunan Nomor 9 Tahun 2019 tentang Pengangkatan Pegawai Negeri Sipil dalam Jabatan Fungsional Auditor, sebagai berikut:

1. Auditor Ahli.

a. Auditor pertama

b. Auditor muda

c. Auditor madya

2. Auditor Terampil. 


\begin{abstract}
a. Auditor pelaksana
b. Auditor pelaksana lanjutan

c. Auditor penyelia

\subsection{Pembahasan}

Dalam melaksanakan fungsi pengawasan oleh Inspektorat Kabupaten Minahasa Utara sebagai auditor internal pemerintah, mengacu pada Peraturan Menteri Dalam Negeri Nomor 107 Tahun 2017, sebagai salah satu kebijakan yang memuat fungsi Inspektorat dalam pengawasan penyelenggaraan pemerintah daerah yang harus diimplementasikan oleh setiap lembaga pengawasan internal pemerintah daerah. Berdasarkan Peraturan Bupati Nomor 72 Tahun 2016, adapun kebijakan-kebijakan yang telah dilaksanakan Inspektorat Kabupaten Minahasa Utara dalam pengimplementasian peraturan yang telah ditetapkan, yaitu:
\end{abstract}

\title{
1. Perencanaan Program Pengawasan
}

a. Dimulai dengan menyusun Program Kerja Pengawasan Tahunan (PKPT) yang terintegrasi dengan dokumen perencanaan daerah;

b. Mereviu Rencana Pembangunan Jangka Menengah Daerah (RPJMD);

c. Penyusunan Rencana Kerja Pemerintah Daerah (RKPD);

d. Penyusunan Rencana Kerja Anggaran (RKA);

e. Menyerahkan RKA ke Tim Anggaran Pemerintah Daerah (TAPD) untuk verifikasi anggaran dan ditelaah kesesuaiannya dan bersama dengan RKA OPD lain dijadikan acuan sebagai bagian penyusunanAPBD. Untuk RKPD dan RKA $2 x$ setiap tahun untuk anggaran induk dan perubahan.

2. Perumusan Kebijakan dan Fasilitas Pengawasan. Inspektorat Kabupaten Minahasa Utara dalam melaksanakan perumusan kebijakan dan fasilitas pengawasan dengan membuat kebijakan pengawasan yang berpedoman pada kebijakan pengawasan pemerintah pusat dan provinsi yang disesuaikan dengan karakteristik daerah. Hal ini untuk menghindari tumpang tindih dalam pelaksanaan fungsi pengawasan dan sinkronisasi program pengawasan mulai dari pemerintah pusat, pemerintah provinsi sampai pada pemerintah daerah. Perumusan kebijakan pengawasan juga mengacu pada hasil evaluasi pada tahun sebelumnya, sehingga bisa disusun kebijakan pengawasan yang sesuai dengan kebutuhan.

3. Pemeriksaan, Pengusutan, Pengujian dan Penilaian Tugas Pengawasan

Pemeriksaan. Dalam melakukan pemeriksaaan oleh Kantor Inspektorat Kabupaten Minahasa Utara, maka ruang lingkup pemeriksaan ditekankan pada pengawasan aparatur pemerintah daerah, pelaksanaan pembangunan daerah, pelaksanaan dalam bidang keuangan serta kesejahteraan sosial. Alasan dilakukan pemeriksaan yaitu untuk menilai apakah terjadi penyimpangan dalam pelaksanaan aktivitas yang dilakukan oleh keempat bidang dalam pemerintah daerah (bidang aparatur, pembangunan, keuangan dan bidang kesejahteraan sosial) selain itu dapat dilakukan tindakan perbaikan dalam pelaksanan aktivitas pemerintah khususnya di Kabupaten Minahasa Utara.

Pengusutan. Pelaksanaan pengusutan sudah tepat waktu dan sesuai sasaran yang hendak dicapai karena adanya koordinasi dan pengolahan data yang baik, hal ini bisa tercapai karena informasi yang didapatkan dari hasil pemeriksaan dan pengujian tidak lambat sehingga mempermudah dalam proses pengusutan.

Pengujian. Dalam melakukan pengujian dengan sejumlah informasi yang diperoleh di lapangan maka data yang didapatkan sudah akurat dan dapat dijadikan sebagai pedoman dalam melakukan pengujian yang valid karena diuji keaslian data yang disajikan.

Penilaian Tugas Pengawasan. Fungsi dan peran auditor internal pemerintah pada Kantor Inspektorat Kabupaten Minahasa Utar perlu dilakukan penilaian tugas pengawasan yang selama ini dilakukan. Hal ini bertujuan untuk menilai apakah pelaksanaan pengawasan yang telah dilakukan telah sesuai dengan yang direncanakan serta usaha untuk 
memberikan petunjuk kepada para pelaksana agar mereka selalu bertindak sesuai dengan rencana.

\section{Pelaksanaan Pengawasan Internal terhadap Kinerja dan Keuangan}

Audit.Pemeriksaan keuangan yang dimaksud yaitu pemeriksaan atas laporan keuangan Organisasi Perangkat Daerah (OPD) dan pemeriksaan terhadap aspek keuangan tertentu. Area cakupan pemeriksaan aspek keuangan daerah yaitu pemeriksaan belanja tidak langsung, belanja langsung, dan pelaksanaan penatausahaan keuangan daerah ke setiap Organisasi Perangkat Daerah (OPD) yang berada di bawah Pemerintah Kabupaten Minahasa Utara termasuk kecamatan dan desa.

Reviu.Reviu dilakukan oleh para pejabat fungsional auditor dan Pengawas Penyelenggaraan Urusan Pemerintah di Daerah (P2UPD) terhadap urusan pemerintah dalam lingkup keuangan maupun non keuangan. Kegiatan reviu ini secara garis besar yaitu reviu terhadap Rencana Kerja dan Anggaran (RKA), reviu Laporan Keuangan Perangkat Daerah dan Pemerintah Daerah, dan reviu Laporan Akuntabilitas Kinerja Instansi Pemerintah (LAKIP).

Evaluasi.Kegiatan evaluasi diadakan pada saat akhir dari sebuah kegiatan. Contoh pelaksanaan evaluasi yang dilakukan oleh Inspektorat Kabupaten Minahasa Utara salah satunya evaluasi terhadap Sistem Akuntabilitas Kinerja Instansi Pemerintah (SAKIP) dan pencapaian kinerja organisasi, upaya yang telah dilakukan dalam melaksanakan SAKIP sampai dilakukan evaluasi dan peningkatan hasil evaluasi yang telah dilakukan.

Pemantauan.Pemantauan yang dilakukan oleh Inspektorat Kabupaten Minahasa Utara yaitu mengawasi pelaksanaan dari tindak lanjut rekomendasi hasil audit, Laporan Hasil Reviu, maupun Laporan Hasil Evaluasi dan Laporan lainnya. Dalam melakukan pemantauan dengan mengawasi hasil dari tindak lanjut yang dilakukan oleh OPD terkait temuan yang ditemukan.

Pengawasan Lain.Selain keempat kegiatan inti dalam melaksanakan pengawasan yang telah dijelaskan diatas, terdapat kegiatan pengawasan lainnya, berupa sosilaisasi pengelolaan hasil pengawasan dan pemaparan hasil pengawasan.

\section{KESIMPULAN DAN SARAN}

\subsection{Kesimpulan}

Inspektorat Kabupaten Minahasa Utara sebagai auditor internal pemerintah memiliki peran yang penting di bidang penatausahaan keuangan. Hal ini dapat dilihat dari tugas pokok dan fungsi yang diimplementasikan dengan fungsi pengawasan yang dilaksanakan yaitu perencanaan program pengawasan, perumusan kebijakan dan fasilitas pengawasan serta pemeriksaan, pengusutan, pengujian dan penilaian tugas pengawasan serta pengawasan terhadap kinerja dan keuangan. Selain mengawal dan memeriksa auditor internal pemerintah juga berperan dalam mendeteksi kecurangan. Inspektorat Kabupaten Minahasa Utara sebagai auditor internal pemerintah tidak hanya berperan sebagai pihak yang mengawasi (watch dog) dan memeriksa kesalahan sajatetapi juga bersifat kemitraan(partnership) melalui kegiatankegiatan konsultasi (consuling). Namun, yang menjadi perhatian khusus yaitu jumlah sumber daya manusia/auditor masih kurang.

\subsection{Saran}

1. Inspektorat Kabupaten Minahasa Utara harus terus melakukan perubahan dan memaksimalkan tugas pokok dan fungsi dengan melatih dan membina auditor dalam menerapkan disiplin kerja, serta meningkatkan pembinaan Pegawai Negeri Sipil (PNS) secara berkala dengan melakukan sosialisasi akan bahaya korupsi dilakukan ke seluruh lapisan masyarakat, sehingga pemerintah dan masyarakat saling bekerjasama agar terwujudnya pemerintahan yang baik (Good Governance) dan pemerintahan yang bersih (Clean Governance). 
2. Inspektorat Kabupaten Minahasa Utara juga perlu adanya penambahan jumlah SDM/auditor sesuai kebutuhan organisasi dan mencukupi kebutuhan pegawai pada bidang pengawasan dengan mengikutsertakan para pegawai Inspektorat dan yang ada sekarang dimaksimalkan dalam kegiatan bimbingan teknis (bimtek) serta pendidikan dan pelatihan (diklat).

\section{DAFTAR PUSTAKA}

Ardiyanti, M. T., Djasuli, M., \& Harwida, G. A. (2016). Peran Inspektorat Kabupaten Sumendep dalam pengawasan pengadaan barang milik daerah. Jurnal Paramator, 9(1), 1-7. https://journal.trunojoyo.ac.id/pamator/article/view/3362

Bahri, S. (2016). Pengantar akuntansi. Yogyakarta: Andi.

Erlina., Rambe, O.S., \& Rasdianto. (2015). Akuntansi keuangan daerah berbasis akrual. Jakarta: Salemba Empat.

Fransiska, K., \& Betri. (2014). Pengaruh independensi, pengalaman kerja, kompetensi, dan etika auditor terhadap kualitas audit (Studi kasus pada Kantor Akuntan Publik di Kota Palembang). Jurnal akuntansi, 1-12. https://docplayer.info/32323865-Fransiskakovinna-betri-jurusan-akuntansi-stie-mdp.html

Kartikahadi, H., Sinaga, R. U., Syamsul, M., \& Siregar, S.V. (2016). Akuntansi keuangan berdasarkan SAK berbasis IFRS. Jakarta: IAI.

Damopoli, M. G., Rengkung, L. R., \& Ngangi, C. R. (2017). Fungsi pengawasan Inspektorat terhadap perangkat daerah pemerintah Kota Manado. 13(1), 269-276. https://doi.org/10.35791/agrsosek.13.1A.2017.16146

Mulyadi. (2017). Sistem akuntansi. Jakarta: Salemba Empat.

Oktavia, M. (2005). Analisis faktor-faktor yang memotivasi pemilihan karir bagi mahasiswa akuntansi (Studi kasus pada Universitas Widyatama). http://repository.widyatama.ac.id/xmlui/handle/123456789/584

Pangkey, I., \& Pinatik, S. (2015). Analisis efektivitas dan efisiensi anggaran belanja pada Dinas Kebudayaan dan Pariwisata Provinsi Sulawesi Utara. Jurnal EMBA, 3(4), 3334. https://ejournal.unsrat.ac.id/index.php/emba/article/view/10581

Ratmono, D., \& Sholihin, M. (2015). Akuntansi keuangan daerah berbasis akrual. Edisi Pertama. Yogyakarta: UPP STIM YKPN.

Raya, C. F. (2016). Pengaruh profesionalisme, etika profesi, dan independensi auditor terhadap pertimbangan tingkat materialitas. https://www.semanticscholar.org/author/122907361

Rusdiana., \& Saptaji, A. (2018). Auditing syariah akuntabilitas sistem pemeriksaan laporan keuangan. Bandung: CV. Pustaka Setia.

Siradja, N. G., Alam, A. S., \& Samsu, S. (2015). Analisis pelaksanaan pengawasan Inspektorat Daerah terhadap kinerja Badan Pengawasan Kepegawaian Daerah Kota Baubau. Jurnal Ilmu Pemerintahan, 5(2), 75-84. https://journal.unhas.ac.id/index.php/government/article/view/1361

Wibowo. (2016). Manajemen kinerja. Edisi Kelima. Jakarta: PT. Rajagrafindo Persada.

Wijayanto, P. A. (2017). Pengaruh kompetensi, independensi, profesionalisme auditor internal pemerintah terhadap kualitas audit (Studi kasus pada auditor perwakilan Badan Pengawasan Keuangan dan Pembangunan Daerah Istimewa Yogyakarta). 5(8). http://eprints.uny.ac.id/55608 